НАУКОВИЙ ВІСНИК

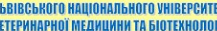
імені с.з. гжицьког Scientifici messenger of L Liv National University of
Veterinary Medicine and Biotechnologies

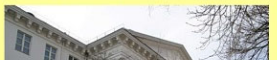

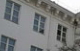
III in

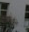

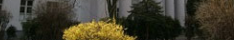
СРРІЯ “ЕКОНОМІчН НАУК 1097 2021
Науковий вісник Дьвівського національного університету ветеринарної медицини та біотехнологій імені С.3. Гжицького. Серія: Економічні науки

\author{
Scientific Messenger of Lviv National University \\ of Veterinary Medicine and Biotechnologies. \\ Series: Economical Sciences
}

UDC 637:338.439.52(477)

\title{
Consisting and prospects of self-sufficiency level increase of the main livestock products in Ukraine
}

\author{
V. Maksym, V. Chemerys, V. Dushka \\ Stepan Gzhytskyi National University of Veterinary Medicine and Biotechnologies Lviv, Lviv, Ukraine
}

Article info

Received 14.09.2021

Received in revised form 14.10.2021

Accepted 15.10.2021

Stepan Gzhytskyi National University of Veterinary Medicine and Biotechnologies Lviv, Pekarska Str., 50, Lviv 79010, Ukraine. Tel.: +38-097-587-01-77 E-mail:volodiamaxym88@gmail.com
Maksym, V., Chemerys, V., \& Dushka, V. (2021). Consisting and prospects of self-sufficiency level increase of the main livestock products in Ukraine. Scientific Messenger of Lviv National University of Veterinary Medicine and Biotechnologies. Series: Economical Sciences, 23(97), 19-23. doi: 10.32718/nvlvet-e9704

The state food security near-term depends on the balanced development of agriculture on the whole and separate directions of agrarian business, which produce raw material and prepared food for providing necessities of internal market consumption. The agri-food subcomplex of Ukraine is characterized strengthening disadvantages between a plant-grower and livestock. More resources particular branch are concentrated on the production of agricultural cultures of feed and technical value, considerable volume of which Ukraine export for the necessities of other countries, forgetting about needs and possibilities of domestic AIC. In the article conducted analysis of self-sufficiency level on the basic types of livestock products in Ukraine that taking into account influence on forming of national food security. A statement of meat and meat products analysis is conducted after basic kinds, eggs, milk and dairy products in Ukraine during 2018-2019 years. Certainly level of self-sufficiency on the basic livestock products in Ukraine, and also taking into account the rational norms of consumption. It is set as a result of research, that the greatest level of self-sufficiency of the poultry farming products, namely by poultry meat and eggs $-126 \%$. A production of pig meat volume in Ukraine does not provide the annual fund of consumption, which is compensated thorough import in a volume over 100 thousand ton during 2019 year. Level of self-sufficiency and other types of meat pork, does not exceed $88 \%$. Deepening of the crisis phenomena is observed in the cattle breeding which is characterized rapid reduction of cows, in particular in the households through low purchase prices on milk and difficult social and demographic processes. Although a production of milk, beef and veal, volume in Ukraine answers the necessities of internal market development, however through annual reduction of cows head in a long-term prospect there will be a deficit of the cattle breeding products, which will be provided through import deliveries that negatively will influence on the state food security. With the purpose of strengthening the food security in Ukraine it is necessary to inculcate the system of measures financial, organizational, economic and technological direction.

Key words: livestock, food security, production, export, import, fund of consumption.

\section{Стан та перспективи підвищення рівня забезпеченості основними видами продукції тваринництва в Україні}

\author{
В. Максим, В. Чемерис, В. Душка
}

Львівський націіональний університет ветеринарної медицини та біотехнологій імені С. 3. Гљицького, м. Львів, Україна

\footnotetext{
Продовольча безпека держави першочергово залежить від збалансованого розвитку галузі сільського господарства загалом та окремих напрямів аграрного бізнесу, які виробляють сировину та готову продукцію для забезпечення потреб внутрішнього споживчого ринку. Агропродовольчий підкомплекс Украйни характеризується посиленням дисбалансу між рослинництвом та тваринництввом. Усе більше галузевих ресурсів скониентровуються на виробництво сільськогосподарських культур кормового та технічного значення, значна частина обсягу яких спрямовується на експорт для потреб інших держав, забуваючи про потреби та можли-
} 
вості вітчизняного АПК. У статті проведений аналіз рівня забезпеченості основними видами продукиї тваринництва в Україні з врахуванням впливу на формування начіональної продовольчої безпеки. Проведено аналіз балансу м'яса та м'ясопродуктів за основними видами, яєць, молока та молокопродуктів в Україні за 2018-2019 рр. Визначено рівень самозабезпеченості основними продуктами тваринництва в Україні, а також з врахуванням раціональних норм споживання. За результатами дослідження встановлено, щуо найвищий рівень самозабезпеченості продукиією птахівництва, а саме м'ясом птиці та яйцями - 126 \%. Обсяг виробництва м'яса свиней в Украӥні не забезпечує річний фонд споживання, який компенсується імпортом в обсязі понад 100 тис. т. за підсумками 2019 р. Рівень забезпеченості свининою та інших видів м'яса, не перевищує 88 \%. Поглиблення кризових явиш спостерігається у скотарстві, щчо характеризується швидким скороченням поголів'я корів, зокрема у господарствах населення через низькі закупівельні ціни на молоко та складні соціально-демографічні процеси. Хоча обсяг виробництва молока, яловичини та телятини в Україні відповідає потребам внутрішнього ринку, однак через щорічне скорочення поголів'я корів у довгостроковій перспективі виникне дефіцит продукції скотарства, який забезпечуватиметься імпортними поставками, щзо негативно впливатиме на продовольчу безпеку держави. 3 метою посилення продовольчої безпеки Украӥни необхідно впроваджувати систему заходів фінансового, організачійно-економічного та технологічного спрямування.

Ключові слова: тваринництво, продовольча безпека, виробництво, експорт, імпорт, фонд споживання.

\section{Ветуп}

Україна займає перше місце за площею орних земель у Європі та володіс найбільшим на континенті виробничим потенціалом розвитку сільського господарства, який не реалізований та значною мірою недооцінений. Найбільшою галуззю в аграрному секторі економіки є рослинництво зернофуражного напряму спеціалізації, яке орієнтоване в основному на експорт, що забезпечує продовольчу безпеку інших держав світу. Лише десята частина від усього вирощеного зерна скеровується на потреби вітчизняного тваринництва, яке не забезпечує у повній мірі продовольчу безпеку за такими категоріями товарів, як м'ясо та м'ясопродукти, що стимулює притік імпорту продукції. Проблема також поглиблюється низьким рівнем споживання основних продуктів тваринництва, який не відповідає науково обгрунтованим нормам. Тому, дослідження стану та перспектив підвищення рівня забезпеченості продукцією тваринництва в Україні набувають значної актуальності, оскільки рівень забезпеченості продовольством є невід'ємною складовою економічної безпеки та стабільного розвитку держави.

Дослідженням продовольчої безпеки України та інших держав світу присвячені наукові праці багатьох вчених економістів, зокрема: Я. Алєксєєва, К. Голікова, Н. Даниленко, В. Дудар, 3. Живко (Zhyvko et al., 2019), І. Іртищева (Irtyshcheva et al., 2020), Г. Колісник, Н. Клименко (Klymenko, 2020), I. Крамаренко, (Kramarenko et al., 2018). П. Музика, В. Немченко, Ю. Пасічник, Л. Рогатіна, М. Стадник, G. Forero-Cantor, J. Ribal, N. Sanjuán (Forero-Cantor et al., 2020), H. Kang (Kang, 2015) та інших.

Продовольча безпека - це захищеність життєвих інтересів людини, яка виражається у гарантуванні державою безперешкодного економічного доступу людини до продуктів харчування з метою підтримання іiі звичайної життєвої діяльності (Pro derzhavnu pidtrymku..., 2004).

Важливою умовою зміцнення продовольчої безпеки є постійний контроль над системою показників її оцінки та прийняття необхідних рішень на всіх рівнях управління щодо ії регулювання. Продовольча безпека переважно оцінюється показниками фізичної достатності та економічної доступності продуктів харчування, їх безпеки, рівнем самозабезпечення країни необхідними продуктами харчування (Zhyvko et al., 2019).

Проблеми з продовольчою безпекою особливо актуальні в Україні, оскільки, незважаючи на достатню кількість споживаних калорій на душу населення, структура споживчого кошика погіршується (Klymenko, 2020). Тому забезпечення населення продуктами харчування високої якості є головною стратегічною метою кожної країни, що сприятиме підвищенню рівня демографічної ситуації та забезпечить соціально-економічний розвиток країни. Відповідно аналіз продовольчої безпеки як важливого елементу економічної та національної безпеки в сучасних умовах господарювання є досить актуальним (Irtyshcheva et al., 2020). Проте дослідження рівня забезпеченості основними продуктами тваринництва в Україні потребують систематичного поглиблення та постійного моніторингу.

Мета дослідження. Визначення рівня забезпеченості основними видами продукції тваринництва в Україні. Основні завдання: дослідження балансу продукції тваринництва в Україні; визначення рівня забезпеченості основними продуктами тваринництва, у тому числі 3 врахуванням науково обгрунтованих норм споживання.

\section{Матеріал і методи досліджень}

При досліджені стану та динаміки рівня забезпеченості продукцією тваринництва в Україні використані дані державного комітету статистики України, аналіз яких проведено з використанням загальнонаукових методів дослідження, зокрема монографічного методу, аналізу, синтезу, індукції, дедукції, наукової абстракції, а також розрахунково-конструктивного та балансового методів при визначені та аналізі рівня самозабезпеченості основними видами продукції тваринництва в Україні.

\section{Результати та їх обговорення}

Тваринництво в Україні формує близько 20 \% усієї вартості аграрної продукції та значною мірою забезпечує продовольчу безпеку держави. Основними видам продукції тваринництва за критерієм вартості виробленої продукції $є$ молоко та молокопродукти, м'ясо птиці, свинина, яйця, яловичина та телятина. 
Загалом в Україні за 2019 р. виробництво м'яса та м'ясопродуктів становило 2492 тис. т, що на $6 \%$ більше ніж у попередньому році (Табл. 1). Фонд споживання м'яса складає $90 \%$ від обсягу виробництва та становить 2252 тис. т. за 2019 р., що на 20 тис. т біль- ше ніж у 2018 р. В середньому на одного жителя припадає близько 54 кг обсягу споживання м'яса та м'ясопродуктів, що значно менше від рекомендованої норми, яка становить 80 кг.

\section{Таблиця 1}

Баланс м'яса та м'ясопродуктів в Україні за основними видами, 2018-2019 pp., тис. т

\begin{tabular}{|c|c|c|c|c|c|c|c|c|c|c|c|}
\hline \multirow[b]{3}{*}{ Показники } & \multicolumn{5}{|c|}{$2018 \mathrm{p}$. } & \multicolumn{5}{|c|}{$2019 \mathrm{p}}$. & \multirow{3}{*}{$\begin{array}{l}2019 \text { р. } \\
\text { у \% до } \\
2018 \text { р. } \\
\text { (м'ясо) }\end{array}$} \\
\hline & \multicolumn{5}{|c|}{ у тому числі } & \multicolumn{5}{|c|}{ у тому числі } & \\
\hline & М'ясо & $\begin{array}{c}\text { Ялови- } \\
\text { чина і } \\
\text { теля- } \\
\text { тина } \\
\end{array}$ & $\begin{array}{l}\text { Сви- } \\
\text { нина }\end{array}$ & $\begin{array}{l}\text { М'ясо } \\
\text { птиці }\end{array}$ & $\begin{array}{l}\text { Інші } \\
\text { види } \\
\text { м'яса }\end{array}$ & М'ясо & $\begin{array}{c}\text { Ялови- } \\
\text { чина і } \\
\text { теля- } \\
\text { тина }\end{array}$ & $\begin{array}{l}\text { Сви- } \\
\text { нина }\end{array}$ & $\begin{array}{l}\text { М'ясо } \\
\text { птиці }\end{array}$ & $\begin{array}{c}\text { Інші } \\
\text { види } \\
\text { м'яса }\end{array}$ & \\
\hline Виробництво & 2355 & 359 & 703 & 1259 & 34 & 2492 & 370 & 708 & 1381 & 33 & 105,8 \\
\hline Зміна запасів & -3 & -2 & -3 & 2 & 0 & 4 & 1 & 1 & 2 & 0 & - \\
\hline Імпорт & 283 & 14 & 128 & 133 & 8 & 261 & 14 & 105 & 136 & 6 & 92,2 \\
\hline Усього ресурсів & 2641 & 375 & 834 & 1390 & 42 & 2749 & 383 & 812 & 1515 & 39 & 104,1 \\
\hline Експорт & 399 & 56 & 9 & 330 & 4 & 487 & 58 & 11 & 417 & 1 & 122,1 \\
\hline $\begin{array}{l}\text { Витрачено на корм, втра- } \\
\text { ти та ін. }\end{array}$ & 10 & 1 & 4 & 4 & 1 & 10 & 1 & 2 & 6 & 1 & 100,0 \\
\hline Фонд споживання & 2232 & 318 & 821 & 1056 & 37 & 2252 & 324 & 799 & 1092 & 37 & 100,9 \\
\hline у розрахунку на 1 особу, кі & 52,8 & 7,5 & 19,4 & 25,0 & 0,9 & 53,6 & 7,7 & 19,0 & 26,0 & 0,9 & 101,5 \\
\hline
\end{tabular}

Джерело: розраховано на основі даних (Balansy ta spozhyvannia..., 2020)

Найбільш розвинутим напрямом тваринництва України є птахівництво, яке характеризується відносно високим рівнем технологічної та алокативної ефективності. У м'ясному балансі України на м'ясо птиці припадає більше половини обсягу споживчого фонду за даними 2019 р. Також птахівництво формує близько 85 \% експорту м'яса та м'ясопродуктів з помітною позитивною динамікою. Так, експорт птиці у 2019 р. по відношенню до 2018 р. виріс на 26\% та досягнув рівня 417 тис. т. при імпорті 136 тис. т.

Обсяг виробництва м'яса свиней в Україні не забезпечує річний фонд споживання, який компенсований імпортом в обсязі понад 100 тис. т. за підсумками 2019 р. Низький рівень виробництва свинини, який становить близько 700 тис. т, негативно впливає на продовольчу та економічну безпеку держави, оскільки залежність від імпорту створює додатковий тиск на стабільність національної валюти та є чинником неконтрольованого коливання цін на продукцію, що негативно позначається на купівельній спроможності громадян.

Поглиблення кризових явищ спостерігається у скотарстві, що характеризується швидким скороченням поголів'я корів, зокрема у господарствах населення через низькі закупівельні ціни на молоко та складні соціально-демографічні процеси, які широко поширені у багатьох сільських населених пунктах України. В результаті спостерігається зростання виробництва м'яса ВРХ, зумовлене скорочення поголів'я корів, що в майбутньому призведе до дефіциту яловичини та молока на внутрішньому ринку, який звичайно покриватиметься за рахунок імпорту та супроводжуватиметься стабільно зростаючими цінами. Скотарство, як молочного так і м'ясного напряму продуктивності характеризується відносно тривалим циклом відтворення, що пов'язано із біологічними особливостями ВРХ, відповідно процес відновлення вимірюватиметься десятиліттями за умови залучення значних фінансових ресурсів у даний напрям агробізнесу. Збереження та відновлення скотарства України повинно стати пріоритетним напрямом розвитку тваринництва, від якого залежить формування стабільної продовольчої безпеки.

У 2019 р. вироблено 370 тис. т яловичини та телятини, при фонді споживання - 324 тис. т., або 7,7 кг у розрахунку на 1 жителя України. Близько 60 тис. т продукції відправлено на експорт, що становило до $16 \%$ від обсягу виробництва. У структурі виробництва та споживання, на яловичину припадає близько $15 \%$. За 2017-2019 рр. обсяг виробництва молока в Україні знизився на $6 \%$ та становив на кінець досліджуваного періоду 9663 тис. т (табл. 2). Рівень виробництво молока та молокопродуктів знижується кожного року, що зумовлено скороченням чисельності корів у господарствах усіх категорій. Також важливим негативним чинником, який спричинив спад виробництва у молочному скотарстві $є$ низькі закупівельні ціни на молоко, які знижують рівень економічної ефективності виробництва. Разом із скороченням виробництва молока та молокопродуктів в Україні зменшився обсяг їх експорту з 835 тис. т у 2017 р. до 593 тис. т за 2019 р., а обсяг імпорту навпаки виріс у 2,5 рази від 132 до 337 тис. т за аналогічний період. Якщо тенденція у молочному скотарстві не зміниться, Україна до 2030 р. прогнозовано стане одним із найбільших імпортерів молока та молокопродуктів у Свропі, що безумовно негативно впливатиме на продовольчу безпеку держави та спричинить значне зростання цін на продукцію. 
Таблиця 2

Баланс яєць, молока та молокопродуктів в Україні, 2017-2019 pр., тис. т

\begin{tabular}{|c|c|c|c|c|c|c|c|c|}
\hline \multirow{2}{*}{ Показники } & \multicolumn{3}{|c|}{ Молоко } & \multirow{2}{*}{$\begin{array}{c}2019 \text { р. у \% до } \\
2017 \text { р. }\end{array}$} & \multicolumn{3}{|c|}{ Яйця } & \multirow{2}{*}{$\begin{array}{c}2019 \text { p. у \% до } \\
2017 \text { p. }\end{array}$} \\
\hline & 2017 & 2018 & 2019 & & 2017 & 2018 & 2019 & \\
\hline Виробництво & 10281 & 10064 & 9663 & 94,0 & 896 & 932 & 963 & 107,5 \\
\hline Зміна запасів & 33 & 74 & -1 & $-3,0$ & 0 & -2 & 5 & $\mathrm{X}$ \\
\hline Імпорт & 132 & 180 & 337 & 255,3 & 7 & 4 & 5 & 71,4 \\
\hline Усього ресурсів & 10380 & 10170 & 10001 & 96,3 & 903 & 938 & 963 & 106,6 \\
\hline Експорт & 835 & 807 & 593 & 71,0 & 155 & 186 & 198 & 127,7 \\
\hline Витрачено на корм & 1036 & 996 & 969 & 93,5 & 72 & 77 & 78 & 108,3 \\
\hline Втрати & 13 & 12 & 11 & 84,6 & 6 & 4 & 4 & 66,7 \\
\hline Фонд споживання & 8496 & 8355 & 8428 & 99,2 & 670 & 671 & 683 & 101,9 \\
\hline у розрахунку на 1 особу, кг & 200,0 & 197,7 & 200,5 & 100,3 & 15,8 & 15,9 & 16,3 & 103,2 \\
\hline
\end{tabular}

Джерело: розраховано на основі даних (Balansy ta spozhyvannia..., 2020)

У птахівництві, на відміну від інших галузей тваринництва України, спостерігається позитивна динаміка зростання виробництва продукції, зокрема курячих яєць, обсяг яких за досліджуваний період збільшився на 7,5 \%. Близько п'ятої частини виробленої продукції реалізується на експорт. Рівень фонду споживання яєць зростає та становить понад 16 кг у розрахунку на одного жителя держави. За показником вартості виробленої продукції птахівництво до 2025 р. перевищить скотарство та займатиме лідерські позиції в тваринництві України, при умові збереження теперішніх темпів розвитку.

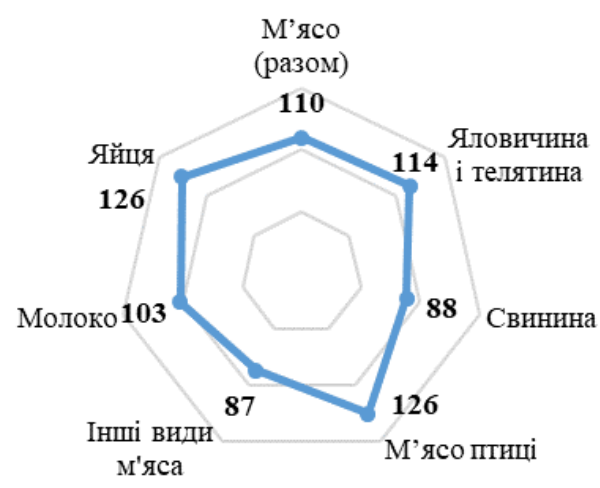

Рис. 1. Рівень самозабезпеченості основними продуктами тваринництва в Україні, 2019 р., \% Джерело: розраховано на основі даних: (Balansy ta spozhyvannia..., 2020)

У 2019 р. найвищий рівень самозабезпеченості продукцією птахівництва - 126\% (Рис. 1). Через низький рівень споживання яловичини та одночасним нарощуванням виробництва на основі скорочення поголів'я корів, рівень забезпеченості за даним напрямом становить 114\%. Найнижчий рівень забезпечення свининою та іншими видами м'яса. Також спостерігається баланс виробництва та споживання молока і молокопродуктів. Перелік необхідних заходів, на наш погляд, повинен включати: адміністративне регулювання цін на рику закупівлі молока, встановлюючи фіксований мінімальний рівень цін не нижче 0,22 Євро /л. для другого гатунку від господарств населення, з метою припинення скорочення поголів'я корів; розвиток конкуренції, поширення пунктів про- дажу, спеціалізованих фермерських магазинів на місцевих ринках; розвиток системи дорадництва, створення аграрних інвестиційних фондів із використанням функціональних онлайн платформ; доступ до фінансових ресурсів, зокрема позикових за пільговими умовами під 1-1,5 \% річної ставки; поширення та підтримка ферм сімейного типу у тваринництві; розвиток спеціалізованих племінних господарств; поширення ресурсозберігаючих інноваційних технологій у тваринництві тощо.

Варто зазначити, що відносно високі показники самозабезпеченості за основними категоріями продукції тваринництва $є$ наслідком відносно низького рівня споживчого фонду за винятком м'яса птиці та яєць. Відповідно актуальним є визначення рівня забезпеченості 3 врахуванням науково обгрунтованих показників споживання основних видів продукції тваринництва (рис. 2).

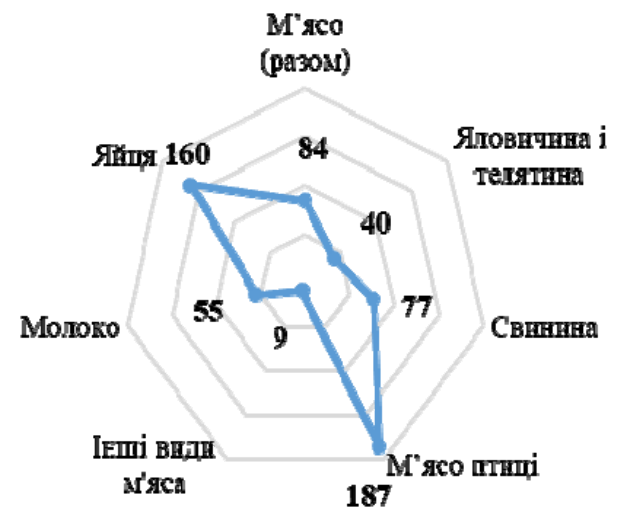

Рис. 2. Рівень самозабезпеченості основними продуктами тваринництва в Україні відповідно до раціональних норм споживання, 2019 р., \%

Джерело: розраховано на основі даних: (Balansy ta spozhyvannia..., 2020) та власних досліджень

За нашими розрахунками, найвищий рівень забезпечення внутрішнього споживчого ринку основних видів продукції тваринництва скорегованого з врахуванням норм раціонального споживання за такими категоріями товарів, як м'ясо птиці та яйця. В усіх інших видах продукції тваринництва рівень самозабезпеченості $\epsilon$ низький. Найбільш критичний рівень забезпеченості в м'ясі та м'ясопродуктах, зокрема в баранині, кролятині та яловичині. Потреба за раціона- 
льними нормами в молоці та молокопродуктах забезпечується внутрішнім виробництвом лише на $55 \%$.

Отже, активізація розвитку таких напрямів тваринництва як молочне та м'ясне скотарство, свинарство, вівчарство повинно стати стратегічним пріоритетом державної політики щодо формування продовольчої безпеки України з впровадженням невідкладних заходів фінансового, організаційно-економічного та технологічного спрямування 3 метою вирішення існуючих проблем стагнації в зазначених напрямах тваринництва.

Реалізація запропонованих заходів дозволить підвищити виробництво продукції тваринництва для забезпечення продовольчої безпеки України відповідно до науково обгрунтованих раціональних норм споживання. Також розвиток тваринництва повинен відповідати ресурсному потенціалу України у сільському господарстві, який є найбільшим у Свропі, проте не реалізований у повній мірі та значно недооцінений.

\section{Висновки}

Продовольча безпека України суттєво залежить від розвитку тваринництва, окремі напрями якого перебувають у стані стагнації, яка характеризується скороченням поголів'я тварин та спадом виробництва. Найвищий рівень самозабезпеченості продукцією птахівництва, а саме м'ясом птиці та яйцями - $126 \%$. Обсяг виробництва молока, яловичини та телятини в Україні відповідає потребам внутрішнього ринку, однак через щорічне скорочення поголів'я корів у довгостроковій перспективі виникне дефіцит продукції скотарства, який забезпечуватиметься імпортними поставками, що негативно впливатиме на продовольчу безпеку держави. Також спостерігається низький рівень забезпеченості свининою та іншими видами м'яса, який не перевищує 88 \%. 3 метою посилення продовольчої безпеки України необхідно впроваджувати систему заходів фінансового, організаційноекономічного та технологічного спрямування.

Перспективи подальших досліджень. Актуальним напрямом майбутніх досліджень стане економічне моделювання продовольчої безпеки України з врахуванням проблем розвитку рослинництва та тваринництва, а також визначення оптимальних показників розвитку окремих напрямів сільського господарства, які забезпечують внутрішній споживчий ринок основними видами продуктів харчування.

\section{References}

Zhyvko, Z. B., Danylenko, N. B., \& Stadnyk, M. Ie. (2019). Prodovolcha bezpeka Ukrainy: teoretykoanalitychnyi ohliad. Vcheni zapysky TNU imeni V. I. Vernadskoho. Seriia: Ekonomika i upravlinnia, 30(69), 15-23. doi: 10.32838/2523-4803/69-6-4 (in Ukrainian).

Pro derzhavnu pidtrymku silskoho hospodarstva Ukrainy: Zakon Ukrainy (Vidomosti Verkhovnoi Rady Ukrainy. (2004). № 49, st.527) URL: https://zakon.rada.gov.ua/laws/show/1877-15 (data zvernennia: 31.03.2021) (in Ukrainian).

Irtyshcheva, I. O., Rohatina, L. P., \& Ilinytska, O. S. (2020). Prodovolcha bezpeka - vazhlyvyi element ekonomichnoi ta natsionalnoi bezpeky. Ahrosvit, 22, 38. doi: 10.32702/2306-6792.2020.22.3 (in Ukrainian).

Klymenko, N. A. (2020). Rehionalni aspekty prodovolchoi bezpeky Ukrainy. Efektyvna ekonomika, 7. doi: 10.32702/2307-2105-2020.7.56 (in Ukrainian).

Kramarenko, I. S., Shyrokov, M. A., Nikon, D. Ie., \& Bilous, O. A. (2018). Rol investytsiinoho potentsialu u konteksti prodovolchoi bezpeky. Visnyk KhNAU, 3, 433-444. doi: 10.31359/2312-3427-2018-433 (in Ukrainian).

Statystychnyi zbirnyk "Balansy ta spozhyvannia osnovnykh produktiv kharchuvannia naselenniam Ukrainy" za 2019 r (2020). Derzhavna sluzhba statystyky Ukrainy. URL: http://www.ukrstat.gov.ua (in Ukrainian).

Forero-Cantor, G., Ribal, J., \& Sanjuán, N. (2020). Measuring regional differences in food security from access and stability dimensions: A methodological proposal based on elasticities. Agric. Econ. - Czech, 66(3), 112-119. doi: 10.17221/97/2019-AGRICECON.

Kang, H. (2015). A study on the relationship between international trade and food security: Evidence from less developed countries (LDCs). Agric. Econ Czech, 61(10), 475-483. doi: 10.17221/246/2014AGRICECON. 